\title{
Mandibular Alveolar Process
}

National Cancer Institute

\section{Source}

National Cancer Institute. Mandibular Alveolar Process. NCI Thesaurus. Code C160975.

The portion of the mandible that contains the sockets of the teeth. 